\title{
Iron Age farming in the Central European Alpine and Dinaric regions; crop occurrence and distribution
}

\author{
Andrej PAUŠIČ $\check{C}^{\star}$ Andrej ŠUŠEK \\ University of Maribor, Faculty of Agriculture and Life Sciences, Pivola 10, 2311 Hoče, Slovenia
}

\begin{abstract}
The main objective of this paper was to holistically describe the occurrence of most important crop taxa found in different archaeological Iron Age sites in two selected biogeographical regions of Central Europe; in the Alpine and the Dinaric mountains. This study also links the known results of research about the ecological-biogeographical conditions in the Central Europe during the Iron Age time with the papers that include archaeobotanical data of the selected European landscapes as well. It is evident that many factors played crucial roles in the domestication process of many different plant taxa. This study showed that both the Alpine and the Dinaric region of Europe show similar ecological conditions for successfully growing important legumes and cereal taxa. The percentage of found cereal taxa is higher in the Dinaric region as it is in the Alps. In most archaeological sites in the Dinaric mountains, there were no evidence of the production of pulses at all. However, if comparing the whole repertoire of cultivated plant taxa in the Iron Age epoch in both studied regions, one can conclude that there is not much difference in the number of cultivated planted taxa in the Iron Age epoch.
\end{abstract}

Key words: archaeobotany, biogeography, crop domestication, Iron Age, palaeoenvironmental research

\section{INTRODUCTION}

Roughly between $400 \mathrm{BC}$ and $200 \mathrm{AD}$, the Iron Age farming communities were established in many parts of Central European area. Although these communities have been studied for over a century, still there are many open questions about the agricultural techniques and practices, that wait to be answered in the future.

Crop use, occurrence, dynamics, evolution and diversity are today the key topics of many scientific research publications dealing with archaeobotany. They are key issues for archaeologists, landscape ecologists and botanists in the European area. With this paper, we want to present an overview of recent archaeological studies dealing with archaeobotany, or research about the crop taxa occurrence in the Alpine and Dinaric regions of Central Europe.
Our main objective was to holistically describe the occurrence of most important crop taxa found in different archaeological Iron Age sites in the two selected biogeographical regions of Central Europe; in the Alpine and Dinaric regions. It is evident that many factors played crucial roles in the domestication process of many plant taxa. With this work, we also tried to link the papers/research about the ecological and biogeographical conditions in the Central Europe during the Iron Age time with the papers that include archaeobotanical studies of selected European landscape as well.

At the end, we presented the summary of our findings; the links between different crucial anthropogenic, biogeographic and climatic factors, that were responsible for domestication process of many crucial plant taxa and land use changes.

For a better understanding of archaeobotanical interpretation of the crop occurrence in the Iron Age, we 
begin with the chapter, dealing with the establishment of first agricultural communities in Iron Age in Central Europe, continuing with the chapter describing the ecological conditions that influenced the early farming in the Iron Age period.

At the end, the most important archaeobotanical findings, based on resonant published papers are systematically presented in a table, per each archaeological site respectively.

\section{The establishment of agricultural communi- ties in the Alpine and Dinaric regions}

These two studied mountainous regions of western Eurasia are of particular interest for three main reasons:

(A) Both regions represent (among some other regions in Europe) the first cultivation of Near-Eastern plants under climatic and hydrological conditions that were substantially different from those of South-Eastern Europe and the Near East.

Marked seasonality and shorter growing seasons were two critical differences, and the selection of habitats, in which wheats (Triticum spp.) and barleys (Hordeum spp.) could be grown, reflects the increasing agricultural sophistication (Bogucki, 2001).

(B) The animal component of the economy shifted from one in which sheep and goat played the main role, as was the case in South-Eastern Europe and the Near East, to one in which cattle were the dominating domestic animal species (although sheep and goat remained present).

(C) Settlement structure and construction techniques changed from mud brick and adobe to timber structures with wattle and daub walls, reflecting the available raw materials in the forested central Alpine Europe, the Dinaric mountains and its harsher environment.

A major debate in the study of the earliest European farmers is whether they still were local hunters/gatherers who adopted domestic plants and animals and new house forms or whether they were already colonists who settled in the major river valleys of central and northern continental Europe during the Iron Age time. Unfortunately, this debate has polarized some of the archaeologists who studied these communities in different ways (Bogucki, 2001).

It is important to remember that this discussion is primarily about the causes of the spread of agriculture in Central Europe, and less about the identities of individual groups involved. The apparent polarity of this debate masks the real facts about complicated family histories and shifting affiliations among locals and immigrants in Central Europe during the Iron Age epoch.

\section{Demographic and Ecological conditions that influenced the Iron Age farming in the Alpine and Dinaric regions of Central Europe}

It is possible to link early farming settlements in Alpine and Dinaric regions of Central Europe very closely with major river systems, although rarely with the major rivers themselves. Each of the principal drainage systems of Central Europe; the Danube, the Elbe, the Rhine, the Meuse, the Oder, and the Vistula - contained large clusters of Iron Age sites and settlements. These settlements are most commonly found along the brooks and small rivers that drain into the major rivers, although sometimes they appear on low terraces along large streams (Bogucki, 2001).

Within these river drainages, settlements usually occur on or near patches of loess soil. It has been suggested that the location of loess was a major determinant of early farming settlement, but a closer examination of the data suggests that this association is a by-product of the selection of specific habitats within these drainages. Most Iron Age settlements are located in terrains characterized more by broad watersheds than slopes steeply down to the streams, where alluvium from the watersheds recharges the natural fertility of the valley-bottom soils (Bogucki, 2001).

Where such sites are found away from loess, as is the case in the Dinaric mountains and in the Alps (in the Aisne valley of eastern France and other places in central Austria), locations along stream channels with similar alluviation suggest that terrain and hydrology rather than the presence or absence of loess were the primary determinants of settlement location (Poschlod, 2015). Along smaller streams, settlements are found in small clusters.

Although at first glance, these groups, societies may appear to form small villages, closer examination of their stratification and ceramic chronology often indicates that they were instead dispersed farmsteads at which smaller towns, settlements were built and rebuilt at various times (Poschlod, 2015).

Such farmsteads, presumably occupied by a single Neolithic household, appear to be the primary unit of so called Linear Pottery settlement. Over time, the archaeological traces of these farmsteads, consisting of one or more longhouses and their associated pits, accumulated, so that the multiple houses and pits suggest a great density of habitation than was actually the case (Bogucki, 2001).

\section{Climate change versus agricultural practices in Central Europe; a perspective upon crop occurrence in the Alpine and Dinaric regions of Central Europe}

Climate optima (the climate, suitable for sedentary farming practices, enough mild for farming traditional CentralEuropaean crop taxa) (Poschlod, 2015), but also climate pessima (colder climate intervals where, under specific conditions, only cold tolerant crops grew), were found to have strongly affected the origin of settlements in central Europe and the development of the man-made landscape and its habitat and species diversity.

Driving forces for climate changes, until recently, were fluctuations of solar activity and radiation, but also comet impacts and volcano eruptions. It could be shown that climate optima increased landscape, habitat and species diversity as well as the expansion of open man-made habitats (Poschlod, 2015). In the Neolithic Age, the climate optimum favoured 
the settlement of people which created the first anthropogenic habitats, arable fields, pastures and heathlands.

The first climate pessimum period started from the end of the Neolithic Age to the beginning of the Iron Age. At the end of the Neolithic period, around 3400 BC, the climate optimum ended and temperatures cooled down (Poschlod, 2015). The following cold period, called Piora Oscillation (around $3400 \mathrm{BC}$ to $3000 \mathrm{BC}$ ), caused a decline of the tree line (Tinner and Lotter, 2006, Nicolussi et al., 2005) and an expansion of the glaciers in the Alps, as well as a decrease in the dominant tree species Tilia spp. and Ulmus spp. (Lang, 1994). Then the temperatures in Central Europe were around 1 to $2{ }^{\circ} \mathrm{C}$ lower (Poschlod, 2015).

The causes for the cooling are not clear and may have been influenced by orbital changes of the earth around the sun, a decrease of solar activity, or the expansion of polar sea currents (Magny et al., 2006).

Transhumant herding (performed in the ravines and flatland of Central Europe) as well as alpine farming and the farming in the Dinaric mountains, during the Iron Age period have strongly contributed to the decline of forests of Larix decidua and Pinus cembra and, as a consequence, to the lowering of the tree line (Magny et al., 2006). On the other hand, the lack of herding activity has always lead to a secondary succession process, a shift in plant structure and change of soil properties and biogeographical conditions of a particular area (Čarni et al., 2011; Paušič and Čarni, 2012b).
New habitats developed - such as the open pastureland. Alpine pasture weeds such as Rhododendron spp. and alder woodlands (Alnus viridis) increased (Zoller, 1960, Gobet et al., 2004, Tinner and Lotter, 2006). Nowadays, the Rhododendron belts in the Alpine and Dinaric mountain ridges, above the tree line often represent ancient abandoned pastures. Animal herding may have strongly contributed to the enrichment of lowland grassland biodiversity through the transport of seeds from higher to lower altitudes by domestic livestock, but also played a significant role for the more open landscape structure, as being the case nowadays in the areas where open animal grazing is still being performed (Paušič and Čarni, 2012a).

After the first cold epoch and the short optimum which lasted until approximately 1200 BC, another climate pessimum started which was probably the coldest since the last ice age. One cause might have been the outbreak of the Hekla volcano in Iceland (Baker et al., 1995). Glaciers expanded again and alpine farming was abandoned. Crop failures and food supply problems may have been the stimulus for novelties and technological progress. Robust crop plants such as the spelt wheat (Triticum spelta); from Asia Minor, foxtail millet (Setaria italica) and common millet (Panicum miliaceum; both from East Asia), as well as the broad bean (Vicia faba), from Asia Minor were increasingly cultivated (Nasu et al., 2007, Zohary et al., 2012). In the southern Germany, grassland species only increased in the Iron Age, which was interpreted as a signal of permanent open land or

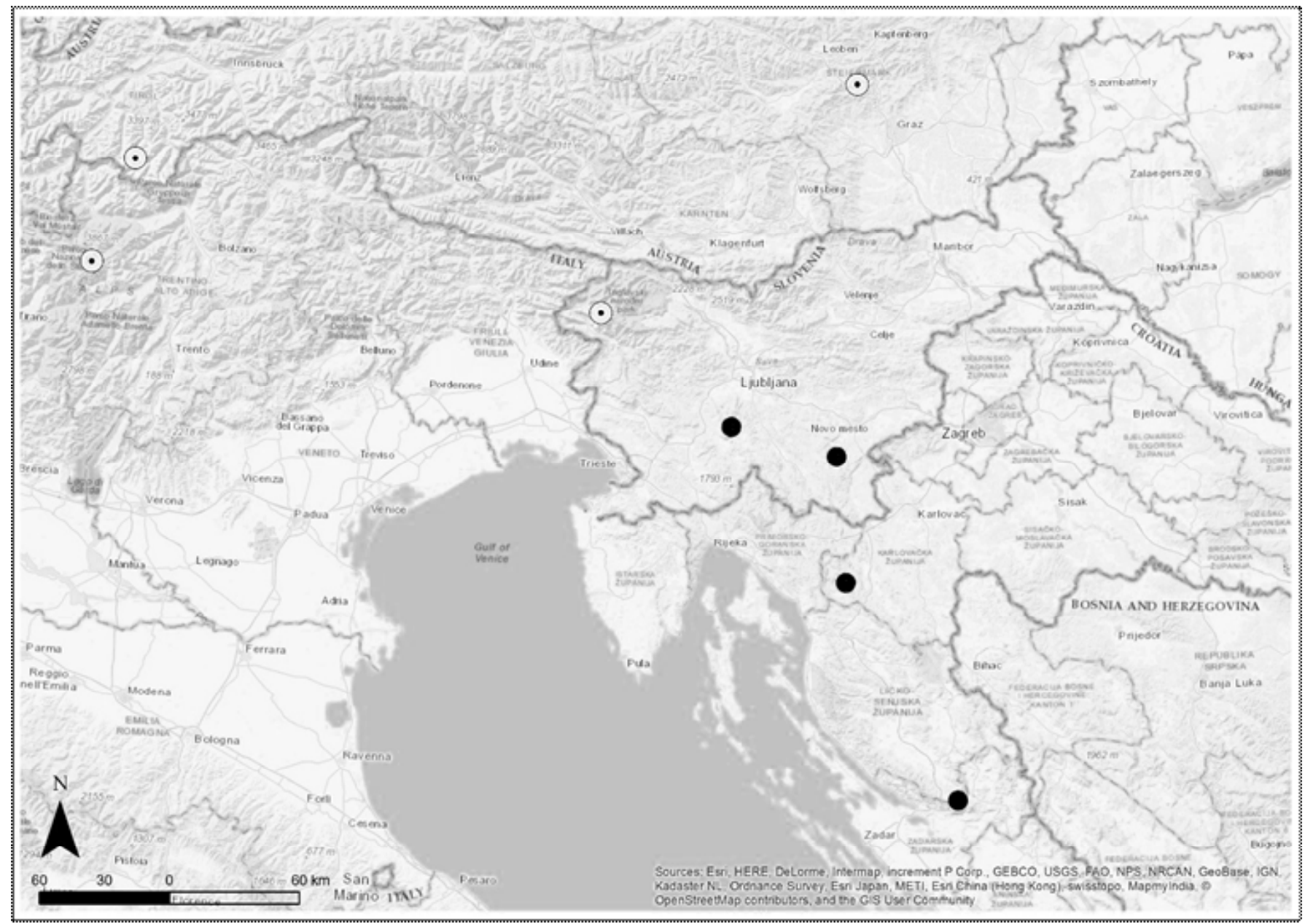

Figure 1: Studied archaeological sites in the Dinaric (black dots) and Alpine mountains (white dots) of Central Europe with the most important excavations sites marked on the map 
grassland. In the eastern part of Europe, which was settled by predecessors of Slavic tribes, meadow use only started as late as the Medieval Age.

\section{MATERIAL AND METHODS}

\section{Occurrence of cultivated plant remnants in the archaeological sites of Alpine and Dinaric regions of Central Europe, based on the recent published papers}

We compared the occurrence of selected crop species and all the other found plant taxa in different archaeological sites of Alpine and the Dinaric mountains of Central Europe (Fig. 1). The evidence for the occurrence of the plant taxa was extracted from studies, papers which deal with the occurrence of crops and legumes in the Alpine and Dinaric regions of Central Europe. Those studies were the primary source for our study and represent the core of our paper.

The first region includes all those archaeological sites (and findings) included in the highest European region - the Alps or the Alpine region (Table 1). The second group consist of a group of archaeological excavation sites, that coincide with the Dinaric mountain range, therefore included in the Dinaric mountain group (Fig. 1, Table 2).

Until now, numerous studies associated with archaeobotany in the CE Alpine region have been performed (Table 1). In the analysis of present Iron Age seed material, found in the Alpine and Dinaric mountain regions, we included the studies from Curdy et al. (1993), Svoljšak et al. (2002), Heiss et al. (2005), Popovtschak (2005) and Schmidl et al. (2007). The studied plant taxa, found during the mentioned research, were arranged in a table according to the plant life forms (Table 1).

\section{RESULTS}

\section{The most Important crop taxa, their ecology and usage in the Alpine and Dinaric regions of Central Europe, based on published papers and studies}

Recent archaeological excavation suggests the Iron Age farming in the Central Europe were indeed sophisticated in that period (Baker et al., 1995, Colledge and Conolly, 2014, Paušič et al., 2019). The remnants of grass/cereal species from the Poaceae family, found in almost all archaeological sites of Iron Age time suggest those taxa were indeed the most important crop species, planted in Central European area.

\section{The Cereals}

The cereals represent an extremely efficient plant food because of the energy and protein provided by their relatively large seeds. Unlike animals, they do not move, they have to be harvested rapidly in one season, and the considerable bulk of the crop requires an organised workforce to harvest, transport and process the grain and straw, as well as facilities to store them - all factors favouring sedentism for cereal farmers.

The wild cereals of the Near East are winter grains adapted to a climatic regime with well-marked wet and dry seasons, and an annual rainfall over $200 \mathrm{~mm}$. The cereal seeds germinate in the spring, ripen rapidly, and disperse the new crop of seeds at maturity. The domesticated taxa have a tough rachis, therefore the seeds are retained in the ear until harvested (Jacomet, 2009).

By far the most important crops, grown in Central Europe in the Iron Age were the wheats and barleys. Of the two primitive wheats, the einkorn (Triticum monococcum) and the emmer (Triticum dicoccum) were the most important taxa. Einkorn was mainly grown in the southern regions in Central Europe while emmer was a staple throughout the western Eurasia. Bread wheat (Triticum aestivum) and club wheat (Triticum aestivum ssp. compactum) were already cultivated in the Iron Age time, but gained in importance over time, particularly when heavier soils were taken into cultivation (Jacomet, 2009).

The spelt wheat (Triticum aestivum ssp. spelta, T. spelta) tended to replace emmer as the mayor wheat in the later time epochs. Einkorn, emmer and spelt are all hulled wheats (having non threshable grains), much more difficult to thresh that bread wheat or club wheat. However, these primitive wheats had several advantages over the others (Stika, 2011, Stika and Heiss, 2013). Spelt and einkorn need less nitrogen than modern crops and are very resistant to weed competition. The importance of emmer lay principally in its ability to tolerate a wide variety of soil and climatic conditions; it also makes fewer demands on the mineral and chemical properties of the soil than some other cereals.

The other, indeed important cereal, grown in the Iron Age time was common barley. Barley comprises several forms among which the most important are two-row and six-row forms, respectively Hordeum vulgare var. distichum and Hordeum vulgare var. hexastichum, both of which could be hulled or 'naked' (having non-threshable or threshable grains, respectively). The early history of this two taxa is rather obscure, but by a large the naked and hulled barleys seem to have been important in the earlier phases of cereal cultivation in Europe, whereas the hulled varieties were preferred in later phases as the threshing technology improved (Zohary et al., 2012).

In many archaeological sites of Iron Age time, the common millet (Panicum miliaceum) is a prevailing crop species. The species is best suited in relatively dry, sandy soils. It has a short growing season, and was especially important in Central and Southern Europe as a crop that could be sown in the spring and would ripen in the time of the summer harvest. In the early Iron Age it may well have been taken into cultivation first in the Balkans (Zohary et al., 2012). 
Because of the ecological conditions where this taxon grows at its best, it was normally absent in the Dinaric mountains and Alps during the Iron Age.

Oat (Avena sativa) and rye (Secale cereale) are thought to have accompanied wheat and barley into Europe as weeds. They began to be cultivated on any significant scale at the end of prehistoric period, and then only in the most northerly regions. Optimum condition for oat resemble those of wheat, but oat can ripen under wetter conditions and on more acid soils, and so can be grown successfully where wheat cannot thrive, e.g., in western Britain and western Ireland, in the Alps and the Dinaric mountains. Rye is normally restricted to light acid soils, such as poor glacial soils of Scotland. It is extremely hardy and can stand cold hard winters better than any other cereal (Schmidl et al., 2007).

\section{Legumes, fodder crops, pasture and fallow}

The excavations on Iron Age sites show that belong the cereals, the legumes were important too. The primary importance of legumes for the farmer is that these crops take nitrogen from the air and, through the symbiotic bacteria in the roots, feed both themselves and the soil itself.

Table 1: Plant remnants (seed) determined in different studies from the Iron Age site in the Alpine region of Central Europe

\begin{tabular}{|c|c|c|c|c|c|c|}
\hline Cereals and other Poaceae & English name & 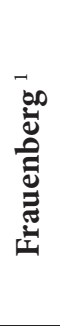 & 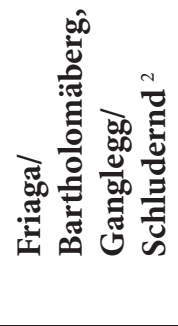 & 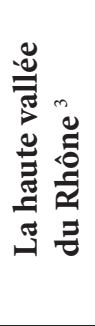 & 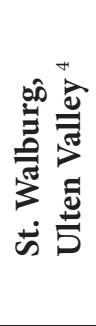 & $\frac{n}{\Xi}$ \\
\hline Avena fatua $\mathrm{L}$. & Wild oat & & $\mathrm{X}$ & & & \\
\hline Avena spp. & Oat & & $\mathrm{X}$ & & & \\
\hline Hordeum vulgare L. & Common barley & $\mathrm{X}$ & $\mathrm{X}$ & $\mathrm{X}$ & $\mathrm{X}$ & \\
\hline Hordeum vulgare var. nudum L. & Naked barley & & $\mathrm{X}$ & & & \\
\hline * Panicum miliaceum L. & Common millet & $\mathrm{X}$ & & $\mathrm{X}$ & $\mathrm{X}$ & \\
\hline Setaria italica (L.) P. Beauvois & Foxtail millet & & $\mathrm{X}$ & $\mathrm{X}$ & $\mathrm{X}$ & \\
\hline Triticum aestivum L. & Bread wheat & & $\mathrm{X}$ & & & \\
\hline Triticum dicoccum Schrank ex Schübl. & Emmer & $\mathrm{X}$ & $\mathrm{X}$ & & $\mathrm{X}$ & \\
\hline Triticum durum Desf. & Durum wheat & & & & $\mathrm{X}$ & \\
\hline Triticum spp. & Wheat & $\mathrm{X}$ & & & $\mathrm{X}$ & \\
\hline Triticum monococcum L. & Einkorn wheat & & $\mathrm{X}$ & & $\mathrm{X}$ & \\
\hline Triticum spelta L. & Spelt & & $\mathrm{X}$ & & & \\
\hline \multicolumn{7}{|l|}{ Pulses } \\
\hline Lens culinaris Medikus & Lentil & & $\mathrm{X}$ & $\mathrm{X}$ & & \\
\hline Pisum sativum L. / Vicia faba L. & Pea /Broad bean & $\mathrm{X}$ & & & & \\
\hline Vicia faba L. & Broad bean & & $\mathrm{X}$ & & $\mathrm{X}$ & \\
\hline \multicolumn{7}{|l|}{ Other taxa } \\
\hline Bromus secalinus L. & Rye brome & & $\mathrm{X}$ & & & \\
\hline Bromus sterilis L. & Barren brome & & $\mathrm{X}$ & & & \\
\hline Bromus tectorum L. & Downy brome & & $\mathrm{X}$ & & & \\
\hline Bromus spp. & Brome & & $\mathrm{X}$ & & & \\
\hline Setaria spp. & Bristle grass & & $\mathrm{X}$ & & & \\
\hline Setaria viridis (L.) P.Beauv. & Green bristle grass & $\mathrm{X}$ & & & & \\
\hline Sherardia arvensis L. & Field madder & & & & $\mathrm{X}$ & \\
\hline Silene spp. & Campion & & $\mathrm{X}$ & & & \\
\hline Vicia ervilia (L.) Willd. & Bitter vetch & & & $\mathrm{X}$ & & \\
\hline
\end{tabular}

* The following taxa belong to the Poaceae family and are not treated as cereals per se, but because of the ecological similarities with the grain taxa we included those taxa in the same category.

${ }^{1}$ Popovtschak (2005), ${ }^{2}$ Schmidl et al. (2007), ${ }^{3}$ Curdy et al. (1993), ${ }^{4}$ Heiss et al. (2005), ${ }^{5}$ Svoljšak et al. (2002) 
Legumes are of two main morphological categories; the taxa that are sown annually, such as peas (Pisum sativum), broad bean (Vicia faba), lupins (Lupinus spp.) and grassland species which stand for several seasons, such as a clover (Trifolium spp.).

Peas prefer light soil and warm sunny conditions, whereas broad bean grow best on the heavier soils, used for wheat. Indeed, this type of soil in Britain and some areas in the Alps were extensively used for been production in the Iron Age time (Zoller, 1960, Schmidl et al., 2007).

\section{Macrobotanical remnants, found in the studied archaeological sites}

Although the included archeological excavation sites belong to the same mountainous geographical region of the Central Europe (Table 1), there are large differences in the number of plant taxa, found in each site. In almost all sites, the common barley is a taxon that was found. The same is true for common millet and the emmer wheat. Indeed, some of those studies suggest the common barley was the main crop in the Alpine region as the taxa could survive and flower even in colder and higher locations (Popovtschak, 2005, Schmidl et al., 2007).

Some recent observations of Jacomet (2009) as well as ethnographic sources describe that the cultivation of barley reaches altitudes up to $2000 \mathrm{~m}$ in the south of Switzerland (Valais, near Zermatt). Since now, there are no evidences that some hulled wheat taxa such as the spelt was cultivated to a such extend or was as important as the hulled barley in the Alpine region during the Iron Age. Spelt itself was found only in one location (the archaeological excavation site of Friaga/ Bartholomäberg).

The lentil as well as the broad bean seed was found in many archaeological Iron Age sites and are therefore considered to be important pulse taxa, that were already common (cultivated) in the Iron Age in the Alpine mountain region. Charred seeds and remnants of lentil were found only in some archaeological excavations in Italy. Therefore, one could suggest or point to the local cultivation of this plant only south of the main Alpine range in the area of the Eastern Alps. In the western alpine region, lentil was found in Valais, Switzerland (Curdy et al., 1993), accompanied by large amounts of Vicia ervilia. Outside of the Alps, lentil is commonly found in Iron Age settlements; both southwards and northwards of the Alps.

Rye is absent in almost all Iron Age archaeological sites in the Alpine area. The species first appears in indeed small

Table 2: Plant remnants (seed) determined in different studies from the Iron Age site in Dinaric mountain region of Central Europe

\begin{tabular}{|c|c|c|c|c|c|}
\hline $\begin{array}{l}\text { TAXON } \\
\text { Cereals and other Poaceae }\end{array}$ & English name & 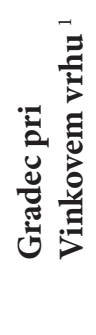 & 莺 & 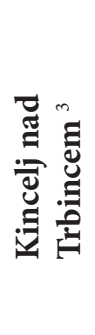 & 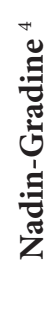 \\
\hline $\begin{array}{l}\text { Avena spp. } \\
\text { Avena sativa } \mathrm{L} . \\
\text { Hordeum vulgare } \mathrm{L} \text {. } \\
\text { * Panicum miliaceum } \mathrm{L} . \\
\text { Secale cereale } \mathrm{L} \text {. } \\
\text { Triticum dicoccum Schrank ex Schübl. } \\
\text { Triticum spp. } \\
\text { Triticum spelta } \mathrm{L} \text {. } \\
\text { Other taxa }\end{array}$ & $\begin{array}{l}\text { Oat } \\
\text { Common oat } \\
\text { Barley } \\
\text { Common millet } \\
\text { Rye } \\
\text { Emmer } \\
\text { Wheat } \\
\text { Spelt }\end{array}$ & $\begin{array}{l}X \\
X \\
X \\
X\end{array}$ & X & $\begin{array}{l}X \\
X\end{array}$ & $\begin{array}{l}X \\
X\end{array}$ \\
\hline $\begin{array}{l}\text { Amaranthus spp. } \\
\text { Setaria spp. } \\
\text { Sinapis arvensis L. } \\
\text { Trifolium spp. } \\
\text { Vicia cracca L. } \\
\text { Vicia spp. }\end{array}$ & $\begin{array}{l}\text { Amaranth } \\
\text { Bristle grass } \\
\text { Field mustard } \\
\text { Clover } \\
\text { Cow vetch } \\
\text { Vetch }\end{array}$ & $\begin{array}{l}X \\
X\end{array}$ & & $\begin{array}{l}X \\
X \\
X\end{array}$ & \\
\hline
\end{tabular}

* The following taxa belong to the Poaceae family and are not treated as cereals per se, but because of the ecological similarities with the grain taxa we included those taxa in the same category.

${ }^{1}$ Culiberg and Šercelj (1995), ${ }^{2,3,4}$ Tecco Hvala (2017) 


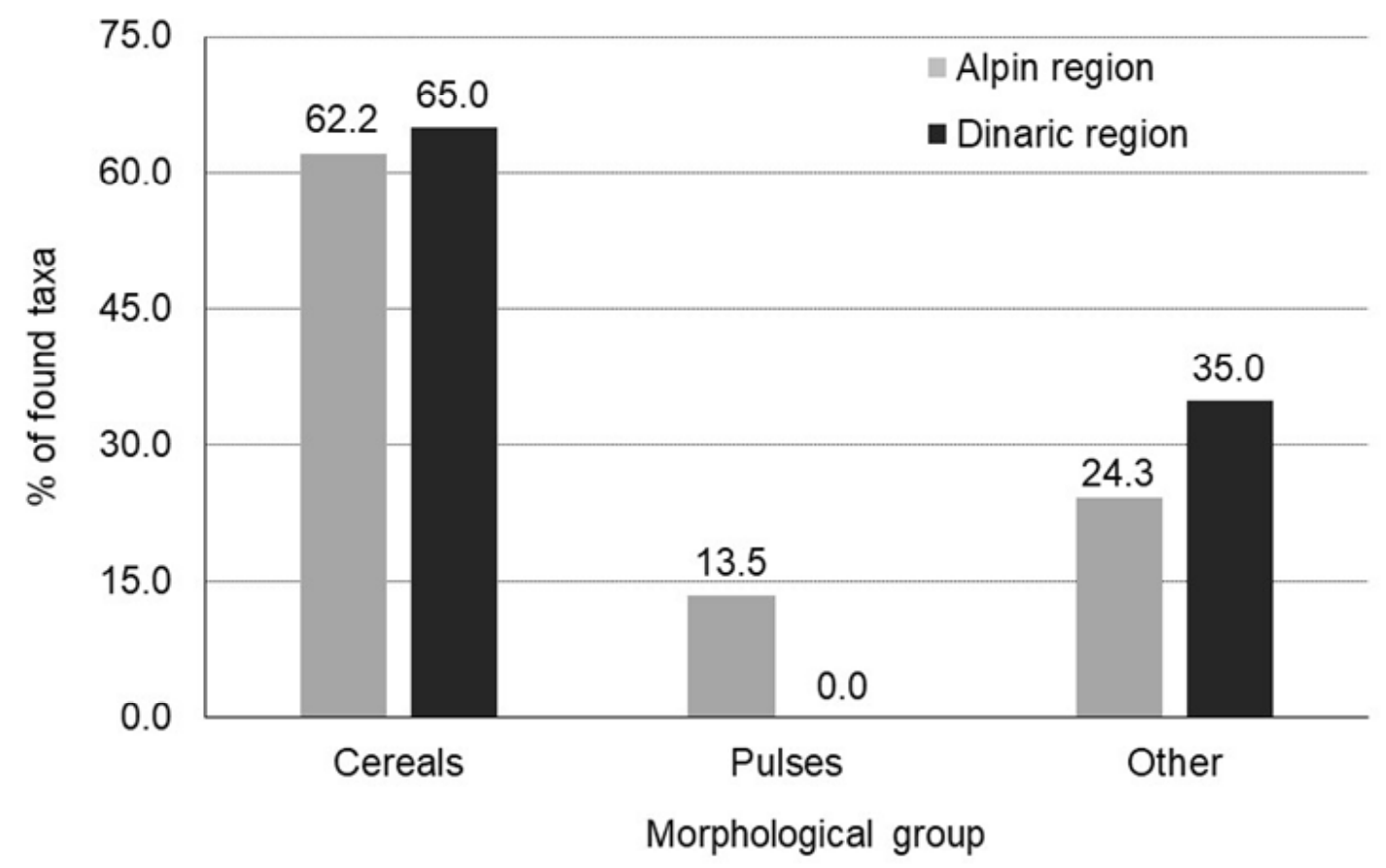

Figure 2: Percentage (\%) of found taxa per morphological group in the archaeological sites of Alpine and Dinaric mountain region

quantities in some Iron Age sites and was therefore considered as a crop. High amounts of Bromus secalinus grains in some archaeological sites, together with hulled barley, spelt and common millet suggest that those taxa were farmed (and harvested) together.

Besides lentil, high amounts of broad bean are found in the samples in the excavations in the Alpine region. Overall, it shows a rather regular presence and was therefore an important crop species in the Iron Age time. Pisum sativum played a role as a pulse, occurring rather regularly in some of the settlements (Table 1 ).

In the Dinaric mountain region (Table 2) it is evident that einkorn is the taxa that is totally absent or was not found in any archaeological site.

The field mustard is a taxon that was not present in Alpine region in the Iron Age epoch. At least the species is not presented as a finding in the archaeological sites of Alpine region (Table 2 )

For a brief comparison, the percentage of found cereal taxa (compared to all plant taxa) included in this study is higher in the Dinaric region (65\% of all found taxa belonged to cereal group) as it is in the Alpine region (62.2\% of all recognised taxa belong to a cereal group) (Fig. 2). We are able to give a brief explanation of such situation; the climatic conditions in the western Dinaric range is more mild than in the Alpine range of Central Europe - therefore much more favourable for the production of cereal taxa.

The even more important fact is that in all the archaeological sites in the Dinaric mountains, we found no evidence of determined remnants of the pulses (Table 2, Fig. 2). It is hard to explain such a situation since the studied taxa from Fabaceae family favour the milder climate, as are the ecological conditions in many parts of the Dinaric mountains region (Fig. 2)

\section{DISCUSSION}

Evidently, in both, the Alpine and the Dinaric region, remnants of many important crop taxa were found. Comparing the archaeobotanical findings in selected Iron Age sites of both studied regions, it is obvious that there is quite a difference in the repertoire of planted taxa from the Iron Age epoch (even some plant genera are absent or were not found or determined in the Dinaric region).

The percentage of found cereal taxa (occurrence of selected taxa in a particular site) is higher in the Dinaric region as it is in the Alps (according to the published data). One should be always careful when comparing different sites according to the plant remnants, found in a specific time scale. The fact is that in many cases we could only take into account the published data; the real evidence of the existence of particular plant taxa.

Often, the remnants (pollen, seed, plant tissues) are preserved in ideal conditions (anaerobic conditions, under favourable pressure etc.) in some archaeological site. Therefore, we should always think about a crowd of material, that could not preserve. Either the environmental conditions were not favourable or the tissues themselves were found in the way they could not be properly determined.

Consequently, such studies show us a wide array of species that occurred in a timescale on a specific place. However, we should always bear in mind that some species, that were used maybe as a food source are missing; the remnants were newer found or determined.

For example, we found no evidence (no published papers) about the occurrence/presence of pulses in the Dinaric region (no plant remnants cited in the studies). However, the soft tissues of pulse seed and other plant remnants, decay fast. Therefore, this might explain the lack of data for those 
taxa. Or, as it is often the fact, there were simple not enough preserved material left, that one could determine properly.

Although we know much more about the earliest farmers of central Europe than we did some years ago, much work still remains to be done in order to understand the spread of farming and the crop occurrence in a specific region or place. The challenges come less from the need to recover additional data and more from the need to analyse the available data in modern ways.

New analytical techniques in archaeobotany, however, hold great promises. It is of critical importance to obtain the idea how plant remnants were really related to each other, in an effort to resolve the question as to whether the specific taxa were brought from somewhere or some of them were indeed indigenous for some region already in the Iron Age epoch. For that purpose, one should obtain larger datasets, including more archaeological, archaeobotanical data.

\section{REFERENCES}

1. Baker, A., Smart, P. L., Barnesm W. L., Edwards, R. L., \& Farrant, A. (1995). The Hekla 3 volcanic eruption recorded in a Scottish speleothem? The Holocene, 5(3), 336-342.

2. Bogucki, P. (2001). Recent research on early farming in central Europe. Documenta Praehistorica, 28, 85-97.

3. Colledge, S., \& Conolly, J. (2014). Wild plant use in European Neolithic subsistence economies: a formal assessment of preservation bias in archaeobotanical assemblages and the implications for understanding changes in plant diet breadth. Quaternary Science Reviews, 101, 193-206.

4. Culiberg, M., \& Šercelj, A. (1995). Karpološke in antrakotomske analize iz prazgodovinskih višinskih naselij na Dolenjskem. Annales, 46(1), 169-176.

5. Čarni, A., Juvan, N., Košir, P., Marinšek, A., Paušič, A., \& Šilc, U. (2011). Plant communities in gradients. Plant Biosystems, 145, 54-64.

6. Curdy, P., Mottet, M., Nicoud, C., Baudais, K., Lindstrom-Baudais, K., \& Moulin, W. (1993). Un habitat alpin de l'age du Fer. Fouilles archeologiques en Valais. Archaologie der Schweiz, 16, 138-151.

7. Gobet, E., Hochuli, P. A., Ammann, B., \& Tinner, W. (2004). Vom Urwald zur Kulturlandschaft des Oberengadins- Vegetationsgeschichte der letzten 6200 Jahre. Jahrbuch Schweizerische Gesellschaft Ur- und Frühgeschichte, 87, 255-270.

8. Heiss, A. G., Kofler, W., \& Oeggl, K. (2005). The Ulten Valley in South Tyrol, Italy: Vegetation and settlement history of the area, and macrofossil record from the Iron-Age cult site of St. Walburg. Palyno-Bulletin, 1, 63-73.

9. Jacomet, S. (2009). Plant economy and village life in Neolithic lake dwellings at the time of the Alpine Iceman. Veget Hist Archaeobot, 18, 47-59.

10. Magny, M., Leuzinger, U., Bortenschlanger, S., \& Haas, J. N. (2006). Tripartite climate reversal in Central Europe 5600-5300 years ago. Quaternary Research, 65, 3-19.

11. Nasu, H., Momohara, A., Yasuda, Y., \& He, J. (2007).
The occurrence and identification of Setaria italica (L.) P. Beauv. (foxtail millet) grains from the Chengtoushan site (ca. 5800 cal B.P.) in central China, with reference to the domestication centre in Asia. Vegetation History and Archaeobotany, 16(6), 481-494.

12. Nicolussi, K., Kaufmann, M., Patzelt, G., Van der Plicht, J., \& Thurner, A. (2005). Holocene tree-line variability in the Kauner Valley, Central Eastern Alps, indicated by dendrochronological analysis of living trees and subfossil logs. Vegetation History and Archaeobotany, 14(3), 221-234.

13. Paušič, A., \& Čarni, A. (2012a). Landscape transformation in the low karst plain of Bela krajina (SE Slovenia) over the last 220 years. Acta geographica Slovenica, 52(1), 35-60.

14. Paušič, A, \& Čarni, A. (2012b). Records of past land use are best stored in soil properties. Plant Biosystems, 147(3), 654-663.

15. Paušič, A., Janžekovič, I., Kotnik, J., \& Šušek, A. (2019). Modern methods and approaches in archaeobotany. In Z. Czajlik, M. Črešnar, M. Doneus, M. Fera, A. Hellmuth Kramberger \& M. Mele (Eds.), Researching Archaeological Landscapes Across Borders - Strategies, Methods and Decisions for the $21^{\text {st }}$ Century (pp. 152161). Budapest, Hungary: Archaeolingua.

16. Poschlod, P. (2015). The Origin and Development of the Central European man-made landscape, habitat and species diversity as affected by climate and its changes a Review. Interdisciplinaria Archaeologica, 6, 197-221.

17. Popovtschak, M. (2005). Verkohlte Pflanzenreste aus dem Bereich des Kultplatzes Frauenberg/Leibnitz, Steiermark (Grabungen 2002-2004). In S. Groh \& H. Sedlmayer (eds.), Der norisch-römische Kultplatz am Frauenberg (Österreich) (pp. 181-194). Lyon, France: Protohistoire Européenne.

18. Schmidl, A., Jacomet, S., \& Oeggl, K. (2007). Distribution patterns of cultivated plants in the Eastern Alps (Central Europe) during Iron Age. Journal of Archaeological Science, 34(2), 243-254.

19. Stika, H. P. (2011). Early Iron Age and Late Mediaeval malt finds from Germany - attempts at reconstruction of early Celtic brewing and the taste of Celtic beer. Archaeological and Anthropological Sciences, 3, 41-48.

20. Stika, H. P., \& Heiss, A. (2013). Plant cultivation in the Bronze Age. In H. Fokkens \& A. Harding (Eds.), The Oxford Handbook of the European Bronze Age (pp. 3560). Oxford, UK: Oxford University Press.

21. Svoljšak, D., Pogačnik, A., Teržan, B., Bartosiewicz, L., Smith- Demo, B., \& Tepina, B. (2002). Tolmin, the prehistoric cemetery II: treatises. In D. Svoljšak \& A. Pogačnik (Eds.), Catalogi et monographiae. Ljubljana, Slovenia: Narodni muzej Slovenije, 139 pp.

22. Tecco Hvala, S. (2017). The Iron Age site at Molnik near Ljubljana. Opera Instituti Archaeologici Sloveniae, 36, 205-210.

23. Tinner, W., \& Lotter, A. F. (2006). Holocene expansions of Fagus sylvatica and Abies alba in Central Europe: where are we after eight decades of debate? Quaternary Science Reviews, 25, 526-549.

24. Zohary, D., Hopf, M., \& Weiss, E. (2012). Domestication 
of Plants in the Old World. The origin and spread of domesticated plants in south-west Asia, Europe, and the Mediterranean Basin. 4th ed. New York, Oxford University Press.

25. Zoller, H. (1960). Pollenanalytische Untersuchungen zur Vegetationsgeschichte der insubrischen Schweiz. Denkschriften der Schweizerischen Naturforschenden Gesellschaft, 83(2), 45-156.

\section{Poljedelstvo v obdobju železne dobe na območju Alp in Dinarskega gorstva Srednje Evrope; pojavljanje in razširjenost pomembnejših vrst poljščin}

\section{IZVLEČEK}

V delu so zbrani arheobotanični popisi rastlinskih makroostankov, najdenih v arheoloških grobiščih iz dveh evropskih biogeografskih regij - Alp in Dinaridov srednje Evrope. Glavni namen preglednega članka je predstaviti najpomembnejše kulturne rastline, ki jih je človek gojil v omenjenih regijah v času železne dobe ter rezultate primerjati med regijami. Delo vsebinsko povezuje ekološko-biogeografske parametre v posamezni regiji s pojavnostjo izbranih oziroma opazovanih vrst poljščin. Evidentno je, da so imeli tekom procesa domestikacije številnih vrst poljščin na območju srednje Evrope pomembno vlogo številni ekološki dejavniki, ki so prispevali k nastanku ti. ekoloških tipov posameznih vrst poljščin; ki uspevajo v tem prostoru še danes. Delo nazorno nakazuje na podobne ekološko-biogeografske značilnosti obeh preučevanih regij; odstotek gojenih vrst žit (v primerjavi z drugimi vrstami poljščin) v času železne dobe je bil na prostoru Dinaridov višji kakor v Alpskem svetu. Na istem območju prav tako nismo našli dokazov oziroma podatkov o gojenju stročnic. Rezultati študije kažejo, da je bilo število gojenih vrst poljščin v obdobju železne dobe v obeh regijah primerljivo.

Ključne besede: arheobotanika, biogeografija, domestikacija poljščin, železna doba, arheološko-okoljske raziskave 